\title{
Surgical Correction of Esophageal Stenosis by Right Aortic Arch Persistence in Two Cats
}

\author{
Ítallo Barros de Freitas', Adriana Marks', Felipe Ribeiro Botelho dos Santos', Alceu Gaspar Raiser' ${ }^{2}$ Alexandre \\ Mazzanti ${ }^{2}$, Raimy Costa Martins ${ }^{3}$, João Pedro Scussel Feranti ${ }^{2}$ \& José Fernando Ibañez ${ }^{1}$
}

\begin{abstract}
Background: Vascular ring anomaly is considered a hereditary change. It occurs when the fourth right aortic arch persists instead of the fourth left aortic arch, forming a vascular ring that compress the esophagus causing esophageal dilatation cranial to the compression site. Diagnosis is based upon anamnesis, physical examination, clinical signs and complementary exams (radiograph, complete blood count and biochemical tests). The clinical treatment is inadequate, since the dilatation persists and tends to progress causing irreversible tissue injury. Surgical correction is indicated and consists of the arterial ligament resection and correction of the esophageal stenosis.

Case: The objective of the current study is to report two case of persistence of right aortic arch in two cats referred to the Veterinary Hospital of the Federal University of Santa Maria. On physical examination the patients were alert, in good nutritional status, adequately hydrated and presented normal colored mucous membranes. Each animal underwent radiography and esophagogram with barium sulphate. The exam demonstrated partial esophageal dilation cranial to the cardiac silhouette, suggestive of vascular ring anomaly. An exploratory thoracotomy was performed in order to achieve the definitive diagnosis. The arterial ligament was resected and esophageal stenosis corrected. Anesthesia, surgery and the postoperative period undergo without any complications. Patients remained hospitalized in the first $24 \mathrm{~h}$ for observation and were discharged after this period. Ten days surgery they returned for revaluation and removal of the skin suture. Four months after the surgical correction the animals underwent a new radiography and esophagogram examination. Radiographic findings evidenced persistence of esophageal dilation and narrowing of the esophageal lumen. Patients were evaluated periodically up to 10 months after surgery, verifying excellent quality of life and remission of clinical signs.

Discussion: Vascular ring anomalies affects both dogs and cats, occurring more commonly in purebred dogs than in mixed breed. The literature reports cases in young Siamese and Persian cats, although the absolute numbers are insufficient to make conclusions about the racial predisposition. This case report enrolled two cases of PRAA in adult mixed breed cats (one male and one female from the same litter). Surgical correction is the recommended treatment for PRAA, either conventional or minimally invasive techniques. To assist the dissection of the fibrous ring and correction of esophageal stenosis we utilized a 22 Fr Foley catheter, introduced through the oral cavity to the esophageal stenotic area. The inflation of the balloon on the constricted area allows visualization of residual fiber rings and facilitates its dissection and removal. The PRAA mortality is associated with late diagnosis and the coexistence of aspiration pneumonia. Therefore, surgery should be performed as soon as possible after the onset of clinical signs, in order to reduce damage to the esophageal muscles and nerves. It is estimated that $80 \%$ of cases survived the postoperative period. In both cases, no clinical signs were observed, and there was a reduction of the esophageal diameter compared with the previous dilation, as well as better esophageal transit. Ten months after surgery, the animals returned for revaluation, presenting adequate body development and good quality of life. As shown in this case report, surgical intervention allowed for the accurate diagnosis and correction of PRAA in cats, with remission of clinical signs and full recovery of the animal.
\end{abstract}

Keywords: cat, regurgitation, megaesophagus, thoracotomy, anomaly. 


\section{INTRODUCTION}

Vascular rings are congenital malformations of great vessels and their branches, that surround the trachea and the esophagus, causing esophageal obstruction signals $[11,16]$. The persistent right aortic arch (PRAA) occurs when the fourth right aortic arch persists instead of the left, which forms the aorta. It is the most common type in dogs, accounting for approximately $95 \%$ of cases reported in the literature.

This anomaly usually causes extraluminal esophageal compression at the level of the heart base. The constriction causes a secondary megaesophagus, usually located cranial to the compression [7,19]. Clinical signs of vascular ring anomalies are mainly caused by esophageal stenosis.

As PRAA is a rare anomaly in cats, the veterinary literature lacks in information about successful outcome for this clinical condition. The objective of this study is to report the successful surgical correction of esophageal stenosis caused by vascular ring in two adult cats from the same litter.

\section{CASE}

Two mongrel cats, one male and one female, from the same litter, with two years old, weighing 3 $\mathrm{kg}$ each, were referred for clinical care at Veterinary Hospital of the Federal University of Santa Maria presenting episodes of regurgitation of semi-digested food and, occasionally, diarrhea. The owners reported volume increase in the cervical region, mostly after feeding, which disappeared after massage.

On physical examination the patients were alert, in good nutritional status, adequately hydrated and presented normal colored mucous membranes. Each animal underwent radiography (Figure 1A) and esophagogram (Figure 1B) with barium sulphate ${ }^{1}$ (Bariogel ${ }^{\circledR}-2 \mathrm{~mL} \mathrm{~kg}^{-1}$ ). The exam demonstrated partial esophageal dilation cranial to the cardiac silhouette, suggestive of vascular ring anomaly.

A complete blood count (CBC) and biochemical tests (glucose, blood urea nitrogen, creatinine, total protein, albumin, alkaline phosphatase, ALT and ALP) were performed. These values were within published reference intervals. According to the anamnesis, clinical signs and radiographic findings, the presumptive diagnosis was esophageal dilatation secondary to vascular ring anomaly. An exploratory thoracotomy was performed in order to achieve the definitive diagnosis.
Anesthetic and surgical techniques were similar for both cats. The pre-anesthetic medication consisted of morphine sulphate ${ }^{1}$ (Dimorf $^{\circledR}-0.4 \mathrm{mg}$ $\mathrm{kg}^{-1}$, i.m.). Cefalexin ${ }^{2}$ Cefalotil $^{\circledast}$ - $30 \mathrm{mg} \mathrm{kg}^{-1}$, i.v.) was administered as prophylactic antibiotic therapy $30 \mathrm{~min}$ before surgery, followed by metamizole ${ }^{3}\left(\right.$ Febrax $^{\circledR}-25$ $\mathrm{mg} \mathrm{kg}^{-1}$, i.v.). Anesthesia was induced with diazepam ${ }^{4}$ (Diazepam ${ }^{\circledR}-0.3 \mathrm{mg} \mathrm{kg}^{-1}$, i.v.) and propofol $^{1}$ (Propo$\operatorname{van}^{\circledR}-4 \mathrm{mg} \mathrm{kg}^{-1}$, i.v.), maintained with isoflurane ${ }^{1}$ (Isoflurane ${ }^{\circledR}$ ) vaporized in $100 \%$ oxygen through a nonrebreathing system. Analgesia was achieved through blockade of the intercostal nerves with lidocaine without epinephrine ${ }^{1}\left(\right.$ Xylestesin $^{\circledR}-4 \mathrm{mg} \mathrm{kg}^{-1}$ ) and constant rate infusion of lidocaine chloride ${ }^{1}$ (Xylestesin ${ }^{\circledR}-50 \mu \mathrm{g}$ $\mathrm{kg}^{-1} \mathrm{~min}$ ) and morphine (Dimorf ${ }^{\circledR 1}-3.3 \mu \mathrm{g} \mathrm{kg}^{-1} \mathrm{~min}$ ) at a rate of $6 \mathrm{~mL} \mathrm{~kg}^{-1} \mathrm{hr}^{-1}$.

Then, each patient was positioned in right lateral recumbency, proceeded antisepsis of the surgical field with alcohol chlorhexidine ${ }^{5}$ (Clorexidina $^{\circledR}$ ) and delimitation with surgical cloths, followed by thoracotomy in the fourth left intercostal space. By accessing the thoracic cavity, esophageal dilatation (Figure 2A) and constriction ring (verifying persistent right aortic arch) were identified. Divulsion (Figure 2B) and exposition of the ligamentum arteriosum were performed with a Mixter forceps, two ligatures were made with 3-0 polypropylene (Figure 2C) (one close to the aorta and one close to the pulmonary artery), followed by section of the ligament with Potts scissors (Figure 2D).

The esophageal stenosis was dilated with a Foley catheter by positioning its balloon caudally to the constriction point. The surgeon verified the correct position and then inflated the balloon with $10 \mathrm{~mL}$ of saline and directed the catheter cranially, emptying the cranial portion of the esophagus. For thoracorraphy, the ribs were approached with nylon 0 suture pattern and intrathoracic negative pressure restored through positive pressure ventilation during the last suture stitch. The scalene, ventral and serratus anterior muscles were individually sutured with polyglactin 910 3-0 simple continuous pattern and the skin with nylon 4-0 Wolff pattern.

The postoperative analgesia consisted of tramadol $^{1}$ (Tramadol $^{\circledR}-3 \mathrm{mg} \mathrm{kg}^{-1}$, TID, v.o.) for three days; metamizole ${ }^{3}$ (Febrax ${ }^{\circledR}-25 \mathrm{mg} \mathrm{kg}^{-1}$, BID, v.o.) for five days and meloxicam ${ }^{6}\left(\right.$ Maxican $^{\circledR}-0.1 \mathrm{mg} \mathrm{kg}^{-}$ ${ }^{1}$, SID, v.o.) for two days. The animals were fed four hours after surgery with small amounts of a pasty ration 
mixture. Patients remained hospitalized in the first $24 \mathrm{~h}$ for observation and were discharged after this period. They received pasty ration four times a day for three weeks. After the third week, normal ration was gradually introduced in the diet. Skin suture was removed 10 days after surgery.

Four months after the surgical correction the animals underwent a new radiography and esophagogram examination. Radiographic findings evidenced persistence of esophageal dilation cranial to the cardiac silhouette and narrowing of the esophageal lumen through the base of the heart (Figure 1C). Ten minutes after contrast administration, small amount of barium sulfate still was in the thoracic esophagus, but most part was observed in the stomach, suggesting adequate progression (Figure 1D).

Patients were evaluated periodically up to 10 months after surgery, verifying excellent quality of life and remission of clinical signs. The animals were fed with normal ration in a vertical position.

\section{DISCUSSION}

Vascular ring anomalies affects both dogs and cats, occurring more commonly in purebred dogs than in mixed breed. Veterinary literature found by the authors reports that large breeds such as German Shepherd, Irish Setter and Boston Terriers weighing more than $15 \mathrm{~kg}$ represents $92 \%$ of the cases $[1,12,15,17,18,20]$.

In cats, the exact incidence of PRAA is unknown. Differently from dog, it is a rare condition, without predilection for race or weight [13]. The literature reports cases in young Siamese and Persian cats, although the absolute numbers are insufficient to make conclusions about the racial predisposition [4,15]. However, the authors reports two cases of PRAA in adult mixed breed cats (one male and one female from the same litter). The authors are unaware of reports in veterinary literature about successful outcome in cats affected with PRAA.

Surgical correction is the recommended treatment for PRAA, either conventional (thoracotomy) or minimally invasive techniques (thoracoscopy) [19]. The thoracoscopy technique is related to better visualization of structures, minor surgical wound and less pain and postoperative discomfort. However, in this report, we performed the conventional technique, which was effective in the treatment of the disease.

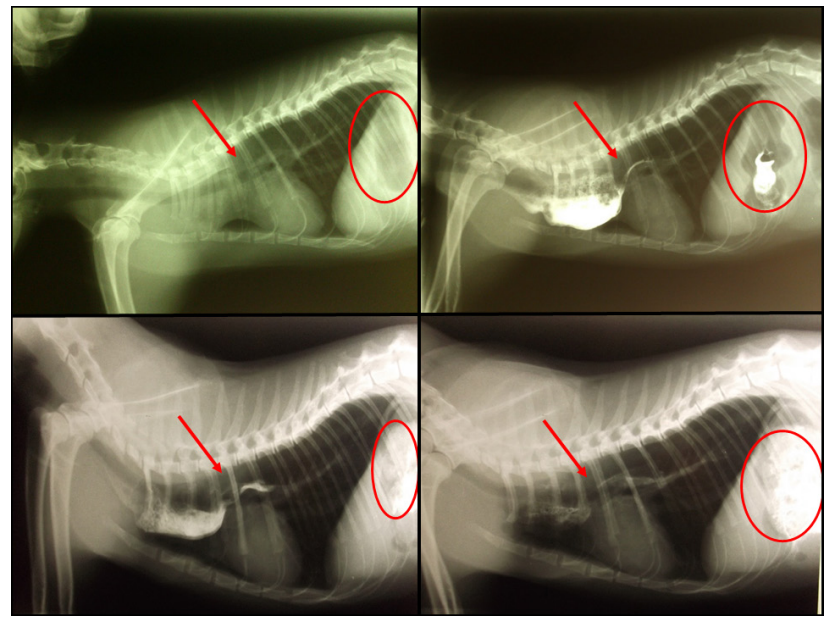

Figure 1. (A) Lateral radiograph suggestive of esophageal dilation cranial to the cardiac silhouette. (B) Esophagogram with barium sulphate demonstrating the partial esophageal dilation and cranial cardiac silhouette. (C) Esophagogram performed four months after surgery, persistence of partial esophageal dilation with difficult passage of contrast to the stomach five minutes after administration. (D) Ten min after barium administration, most part was observed in the stomach, suggestive of adequate progression. * Red arrows showing stenosis and red circles showing the stomach content.

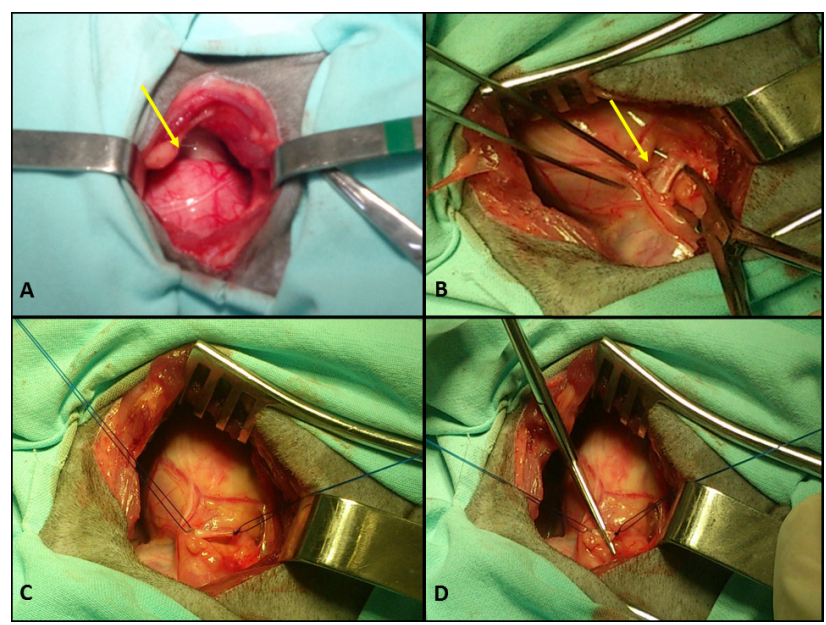

Figure 2. (A) Esophageal dilatation (arrow) can be observed after intercostal thoracotomy (4th space). (B) Identification and exposure of the arterial ligament (arrow) with Mixter forceps for posterior ligature. (C) Two ligatures were made with polypropylene 3-0, one near to the pulmonary artery and one close to the aorta. (D) Section of the arterial ligament with Potts scissors.

To assist the dissection of the fibrous ring and correction of esophageal stenosis, Ellison [4] described the technique with a 22 Fr Foley catheter, introduced through the oral cavity to the esophageal stenotic area. The inflation of the balloon on the constricted area allows visualization of residual fiber rings and facilitates its dissection and removal. The passage of the inflated cuff cranially through the constriction further helps dilate the stenosis and improves esophageal transit. 
The PRAA mortality is associated with late diagnosis and the coexistence of aspiration pneumonia. Therefore, surgery should be performed as soon as possible after the onset of clinical signs, in order to reduce damage to the esophageal muscles and nerves. In this report, although being diagnosed with two years, cats had excellent recovery after surgery, as well as absence of complications such persistent regurgitation and aspiration pneumonia [9].

Complications are common in cases of PRAA due to malnutrition, weakness and aspiration pneumonia [6,13]. Nevertheless, it is estimated that $80 \%$ of cases survived the postoperative period. However, there are numerous studies that report the death of patients in both the trans and postoperative period. $[3,8,10,14,19,21]$. In both cases, no clinical signs were observed, and there was a reduction of the esophageal diameter compared with the previous dilation, as well as better esophageal transit (Figure 1D). Ten months af- ter the procedure, the animals returned for revaluation, presenting adequate body development and according the owners, normal quality of life.

As shown in this case report, surgical intervention allowed for the accurate diagnosis and correction of PRAA in cats, with remission of clinical signs and full recovery of the animal.

\section{MANUFACTURERS}

${ }^{1}$ Cristália Produtos Quimicos Farmacêuticos Ltda. Itapira, SP, Brazil.

${ }^{2}$ União Química Farmacêutica Nacional S/A. Jabaquara, SP, Brazil.

${ }^{3}$ Lema Biologic do Brasil Ltda. Lagoa Santa, MG, Brazil.

${ }^{4}$ Santisa Laboratório Farmacêutico S.A. Bauru, SP, Brazil.

${ }^{5}$ Vic Pharma Industria E Comércio Ltda. Taquaritinga, SP, Brazil.

${ }^{6}$ Ouro Fino Saúde Animal Ltda. Cravinhos, SP, Brazil.

Declaration of interest. The authors report no conflicts of interest. The authors alone are responsible for the content and writing of the paper.

\section{REFERENCES}

1 Buchanan J.W. 2004. Tracheal signs and associated vascular anomalies in dogs with persistent right aortic arch. Journal of Veterinary Internal Medicine. 18(4): 510-514.

2 Castro J.L.C. \& Raiser A.G. 2012. Cirurgia geral esôfago e estômago. In: Oliveira A.L.A. (Ed). Técnicas cirúrgicas em pequenos animais. Rio de Janeiro: Elsevier, pp.271-298.

3 Diaz S.A.C., Ochoa F.A.L., Herrera H.A.P., Sarria C.A.E. \& Hernández J.B. 2010. Corrección de arco aórtico derecho persistente en canino de 11 meses de edad con diagnostico de mega esófago. Revista Electrónica de Veterinaria. 13(10): 1-12.

4 Ellison G.W. 2014. Surgical correction of persistent right aortic arch. In: Bojrab M.J. (Ed). Current Techniques in small animal Surgery. 5th edn. East Simpson: Teton New Media, pp.661-664.

5 Hyun C. \& Park I.C. 2006. Congenital heart diseases in small animals: part II. Potential genetic etiologies based on human genetic studies. Veterinary Journal. 171(2): 256-262.

6 Kyles A.E. 2014. Diseases of the esophagus. In: Johnston S.A. Veterinary surgery small animal. 2nd edn. Saint Louis: Elsevier, pp.1469-1475.

7 Mace S., Shelton G.D. \& Eddlestone S. 2013. Megaösophagus bei hund und katze. Tierärztliche Praxis Kleintiere. 41(2): 123-131.

8 Meireles Y.S., Lopes E.R., Nascimento W.C., Santos M.D.S., Ens M.T.B., Menegassi C.C., Colodel E.M. \& Nespoli P.E.B. 2013. Persistência do arco aórtico direito em um gato siamês. Acta Veterinaria Brasilica. 7(1): 94-95.

9 Oliveira E.C., Gaiga L.H., Colome L.M., Stedile R., Mello F.P.S., Martins J.M. \& Freire C.D. 2004. Persistência do arco aórtico direito em um cão-relato de caso. Revista da Faculdade de Zootecnia VetAgro. 11(1): 85-91.

10 Oliveira A.L.A. 2012. Cirurgia torácica. In: Oliveira A.L.A. (Ed). Técnicas cirúrgicas em pequenos animais. Rio de Janeiro: Elsevier, pp.253-364.

11 Plesman R., Johnson M., Rurak S., Ambrose B. \& Shmon C. 2011. Thoracoscopic correction of a congenital persistent right aortic arch in a young cat. The Canadian Veterinary Journal. 52(10): 1123-1128.

12 Quessada A.M., Fonteles Z.C., Cruz N.E.A., Rodrigues M.C., Freitas M.V.M., Bezerra F.B. \& Sousa J.M. 2010. Persistent right aortic arch in a dog. Acta Scientiae Veterinariae. 38(3): 333-336.

13 Radlinsky M.G. 2014. Cirurgia do esôfago: anomalia de anéis vasculares. In: Fossum T.W. (Ed). Cirurgia de pequenos animais. 4.ed. Rio de Janeiro: Elsevier, pp.456- 461.

14 Rêgo M.S.A., Lima E.R., Leite J.E.B., Silva V.C.L., Ferreira M.A.S., Camargo N.I., Rodrigues T.L., Oliveira 
W.N.K., Silva B.N. \& Lima M.V.F.B. 2009. Megaesôfago em gato atendido no hospital veterinário da UFRPE. In: IX JEPEX (Recife, PE). pp.1-3.

15 Rodrigues B.A., Lamberts M., Muccillo M.S., Martins J.M., Ferreira M.P., Scherer S., Brun C.F.L. \& Lampert M. 2007. Persistência de arco aórtico direito em fêmea da raça american staffordshire terrier tratada cirurgicamente com sucesso: relato de caso. Revista Clínica Veterinária. 67: 32-40.

16Slatter D. 2007. Manual de cirurgia de pequenos animais. 3.ed. Barueri: Manole, 1286p.

17 Sousa-Coelho J.C. \& Alvarez-Hernandez M.G. 2009. Megaesófago por persistencia del cuarto arco aórtico derecho en un perro pastor alemán. Revista de la Facultad de Ciencias Veterinarias Maracay. 50(1): 3-10.

18 Tremolada G., Longeri M., Polli M., Parma P. \& Acocella F. 2013. Persistent right aortic arch and associated axial skeletal malformations in cats. Journal of Feline Medicine and Surgery. 15(2): 68-73.

19 Trindade R.L. 2008. Megaesôfago secundário a persistência de arco aórtico direito em um felino de 2 anos: relato de caso. 26f. Londrina, PR. Dissertação (Pós-Graduação Qualittas em Clínica Médica e Cirurgia), Universidade Castelo Branco.

20 Willard M.D. 2010. Obstrução esofágica: anomalias do anel vascular. In: Nelson R.W. \& Couto C.G. (Eds). Medicina interna de pequenos animais. 4.ed. Rio de Janeiro: Guanabara Koogan, pp.418-423.

21 Yarim M., Gültiken M.E., Özturk S., Sahal M. \& Bumin A. 1999. Double Aortic Arch in a Cat Siamese. Veterinary Pathology. 36(4): 340-341. 